\title{
Detection of Cucumber mosaic virus in commercial anthurium crops and genotypes evaluation
}

\author{
Nancy de S Miura ${ }^{1}$; Luís OS Beriam¹; Eliana B Rivas ${ }^{2}$ \\ ${ }^{1} \mathrm{IB}$, Lab. de Bacteriologia Vegetal, C. Postal 70, 13001-970 Campinas-SP; ${ }^{2} \mathrm{IB}$, Laboratório de Fitovirologia e Fisiopatologia, Av. Cons. \\ Rodrigues Alves 1252,04014-002 São Paulo-SP; rivas@biologico.sp.gov.br
}

\begin{abstract}
In Brazil, Anthurium andraeanum (flamingo flower) stands out as an important species for cut leaves and flowers productions, as well as potted cultivation. Due to the fact that ornamental plants play an important part in the tropical agriculture diversification, there is great interest to know the problems that affect anthurium cultivation in order to improve its productive potential. The aims of this study were identify the causal agent of intense mosaic and leaf deformation observed in anthurium commercial crops from four cities of the São Paulo state, Brazil; to assess the extent of the virus occurrence in these cities and the methods for its detection, as well as to analyse the anthurium genotypes reactions in relation to the virus. Anthuriums were sampled from the following cities: Mogi das Cruzes, PariqueraAçu, Iguape and Registro. Leaves and spathes from symptomatic plants were used in mechanical transmission assays. The virus was transmitted only when spathes were used to prepare the inocula, and it induced Cucumber mosaic virus (CMV)-like symptoms in the indicator hosts. PTA-ELISA and RT-PCR were performed to identify the virus species, since CMV was detected in all agricultural areas sampled. Anthuriums from IAC varieties, 'Jureia', 'Garoa', 'Eidibel' and 'Astral' and from 'Caipira' and 'Branco' cultivars were inoculated with CMV and all of them were susceptible to the virus. Some of the symptoms observed in CMV infected anthuriums although similar to those induced by Dasheen mosaic virus, are more severe for inducing leaf deformation and intensive mosaic. Both viruses are worldwide spread and transmitted by aphid in a non-persistent manner. Although CMV has a wide host range, it was not found in the literature the presence of anthurium as a host to the virus. The eradication of weed plants, mainly Commelina and Tradescantia that are CMV natural hosts, the elimination of the symptomatic anthuriums and control of the aphid population should also be done in the anthurium crop, since anthurium genotypes with resistance for CMV are not available.
\end{abstract}

Keywords: Anthurium andraeanum, Araceae, Cucumovirus, diagnosis.

\section{RESUMO}

Detecção de Cucumber mosaic virus em produção comercial de antúrios e avaliação de genótipos

No Brasil, Anthurium andraeanum tem se destacado como espécie importante para produção de flores e folhas de corte, assim como para cultivo em vaso. Devido ao importante papel das plantas ornamentais na diversificação da agricultura tropical, há grande interesse em conhecer as causas dos problemas que afetam o cultivo de antúrio para melhorar seu potencial produtivo. Este trabalho teve como objetivo identificar o agente causal do mosaico intenso e deformação foliar observados em plantas de antúrios em plantios comerciais em quatro municípios do estado de São Paulo; avaliar a extensão da ocorrência do virus nesses municípios e os métodos para a sua detecção, assim como analisar a reação de genótipos de antúrios em relação a este vírus. Foram amostrados antúrios cultivados em Mogi das Cruzes, Pariquera-Açu, Iguape e Registro. Folhas e espatas de plantas sintomáticas foram utilizadas em ensaios de transmissão mecânica. $\mathrm{O}$ vírus induziu sintomas semelhantes aos observados por Cucumber mosaic virus (CMV), em plantas indicadoras, e só foi transmitido quando espatas foram utilizadas como inóculo. Técnicas de PTA-ELISA e RT-PCR foram realizadas para a identificação do CMV em antúrios de todas as propriedades amostradas. Antúrios das variedades IAC, 'Astral', 'Eidibel', 'Garoa' e 'Juréia', e das cultivares 'Caipira' e 'Branco' foram inoculados com CMV e mostraram-se suscetíveis. Alguns dos sintomas observados em antúrios infectados com CMV, embora se assemelhem aos de Dasheen mosaic virus, são mais drásticos por induzir deformação foliar e mosaico intenso. Ambos os vírus são cosmopolitas e transmitidos de modo não persistente por afídeos. Embora o círculo de hospedeiras do CMV seja amplo, o antúrio não consta dessa lista. A eliminação de plantas invasoras, principalmente Commelina sp. e Tradescantia sp., hospedeiras naturais do CMV, a remoção de antúrios sintomáticos e o controle da população de afídeos são recomendações para a cultura de antúrio, uma vez que não há genótipos resistentes disponíveis.

Palavras-chave: Anthurium andraeanum, Araceae, Cucumovirus, diagnose.

(Recebido para publicação em 10 de abril de 2012; aceito em 29 de janeiro de 2013) (Received on April 10, 2012; accepted on January 29, 2013)

$\mathrm{I}^{\mathrm{n}}$ ornamental horticulture, the genera of Araceae family stands out mainly due to the variety of shapes and colors of the leaves and/or spathes, like Anthurium, Caladium, Philodendron, Spathiphyllum and Zantedeschia (Zettler \& Hartman, 1987). In Brazil, in the beginning of the twentieth century, Anthurium, Alocasia and Dieffenbachia were known as luxury, "aristocratic gardening", considering that Anthurium andreanum, A. coriaceum, A. lucidum, $A$. regale and $A$. scherzerianum were also cited as intensively "cultivated plants in Brazil and abroad" (Figueiredo, 1936).

In the international trade, the commercial value of $A$. andraeanum is only below the commercial value of the orchids (Buldewo \& JaufeerallyFakim, 2002). In Brazil, anthuriums 
commercially grown are varieties and cultivars developed abroad or those of Instituto Agronômico, like 'Astral', 'Cananéia', 'Eidibel' and 'Ômega' (Tombolato et al., 2004).

The anthurium cultivation requires permanent care, due to its susceptibility to mechanical and physiological damages which alter its spathe, spadix and floral stem (Bushe et al., 2004), and consequently depreciating the quality of the product. Besides this susceptibility, damages caused by insects, mites (Guimarães et al., 2008) and diseases, which are barriers to commercial cultivation and exportation, are also observed. In Brazil, numerous pathogens were reported: Xanthomonas axonopodis pv. dieffenbachiae (Robbs, 1953), Acidovorax anthurii (Almeida et al., 2002); Alternaria sp., Cercospora richardiaecola, Cladosporium sp., Colletotrichum falcatum, $C$. gloeosporioides, Fusarium oxysporum, Fusarium sp., Helminthosporium sp., Phoma sp., Phomopsis sp., Phyllosticta sp., Septoria sp., Uredo anthurii, Phytophthora parasitica and Phytophthora sp. (Lacerda, 2006); Dasheen mosaic virus (DsMV) (Rivas et al., 1997) and Anthurium ring spot virus (Ferreira et al., 2004). Among the viruses reported for commercially grown anthuriums, the DsMV is disseminated worldwide (Elliott et al., 1997), but the first report of virus in this plant dates back to 1930 (Verplancke, 1930).

This study aimed to identify the causal agent of the symptoms observed in anthuriums, evaluate the occurrence of Cucumber mosaic virus (CMV) in areas where anthuriums are produced and the methods for its detection, characterize the symptoms associated to the virus, and analyse the anthurium genotype reaction in relation to the virus.

\section{MATERIAL AND METHODS}

Thirty four samples of anthurium (A. andraeanum) consisting of leaves and spathes with symptoms similar to those induced by viruses were collected in areas of commercial production in four cities of São Paulo state. Eleven crop areas were visited, seven in Mogi das Cruzes, two in Registro, one in Pariquera-Açu and another in Iguape. In all producing areas, plants with mosaic, chlorotic spots and rings and/or leaf deformation symptoms were observed, with or without symptoms in spathes (Figure 1).

In the preparation of initial inoculum for the transmission tests, it was verified the rapid oxidation of the foliar extracts and a slower oxidation of extracts from the spathes. In order to determine the best conditions for the inoculum preparation were tested: sodium and potassium phosphate buffer $0.05 \mathrm{M}$, $\mathrm{pH} 7.2+2 \%$ polyvinylpyrrolidone (PBP) with and without $0.5 \% \mathrm{Na}_{2} \mathrm{SO}_{3}$; $1 \% \mathrm{KH}_{2} \mathrm{PO}_{4}$ solution with and without $0.01 \%$ activated charcoal; $0.5 \% \mathrm{Na}_{2} \mathrm{SO}_{3}$ solution, and only PBP. The extracts from leaves or spathes samples were prepared with $1 \mathrm{~g}$ tissue/10 mL buffer or solution. The extracts were rubbed on leaves previously dusted with Carborundum 400 mesh in species of Amaranthaceae, Araceae, Chenopodiaceae and Solanaceae families.

To evaluate the genotypes of $A$. andraeanum in relation to the virus presence, the inoculum was prepared from the indicator plant, in the same ratio mentioned above, and rubbed on two leaves/plant, seven plants of each variety/cultivar. Anthurium seedlings of the four IAC varieties, Jureia, Garoa, Eidibel and Astral, and three cultivars 'Caipira', 'Branco' and an unknown were inoculated at vegetative stage of 3-4 leaves. After inoculation, the plants were kept in a greenhouse.

'Plate Trapped Antigen-Enzyme Linked ImmunoSorbent Assay' (PTAELISA), adapted from Dijkstra \& Jager (1998) was used for serological detection of the virus. Foliar extracts from natural and experimentally infected A. andraeanum, as well as Nicotiana glutinosa and N. sylvestris inoculated with the virus isolated from anthurium were used as antigens. Antiserum against CMV was obtained from the antisera collection of the Laboratorio de Fitovirologia e Fisiopatologia of the Instituto Biológico, and the antiserum against DsMV was provided by Dr. Francis W. Zettler (Florida University, USA).
Total RNAs were extracted from symptomatic and asymptomatic anthurium leaves collected in Mogi das Cruzes and Registro, as well as from cv. Branco and N. glutinosa experimentally inoculated with the virus isolated from anthurium, using RNeasy Plant Mini Kit (Qiagen), according to the manufacturer's protocol. RTPCRs were performed using specific primers for $\mathrm{CMV}, \mathrm{CM} 1$ reverse 5' GCCGTAAGCTGGATGGACAA 3, and CM 2 forward 5, TATGATAAGAAGCTTGTTTCGCG 3' (Wylie et al., 1993). PCR products were analyzed on $1.5 \%$ agarose gel.

\section{RESULTS AND DISCUSSION}

Mechanical virus transmission from the naturally infected anthurium leaves was not possible with the buffers and solutions tested. On the other hand, the transmission to $A$. andraeanum and indicator species occurred when extracts prepared with symptomatic spathes $+\mathrm{PBP}+0.5 \% \mathrm{Na}_{2} \mathrm{SO}_{3}$ (PBPS) were employed (adapted from Mertelik et al., 2002). According to these results, PBPS was used in all biological tests. The difficulty in transmitting a viral species that is easily mechanically transmitted may indicate the presence of secondary metabolic substances in the anthurium leaves, which interfere with transmission or that degrade the viral particle. In order to evaluate the effect of the substances present in the anthurium leaf extract on the virus transmission, an inoculum from leaf extract (1 g anthurium leaf/10mL PBPS) + purified preparation of Tobacco mosaic virus (TMV) in final concentration of 0.5 $\mathrm{mg} / \mathrm{mL}$ was prepared. This inoculum was rubbed on 5 plants of Datura stramonium, 3 leaves/plant. As controls, anthurium leaf extract without TMV and the purified TMV preparation, at the same concentration above, were used. The average number of necrotic local lesions in datura leaves was 145 when inoculated with TMV and 31 in the ones inoculated with anthurium extract + TMV. The datura leaves inoculated only with the anthurium extract did not show symptoms. The influence of the substances present in 


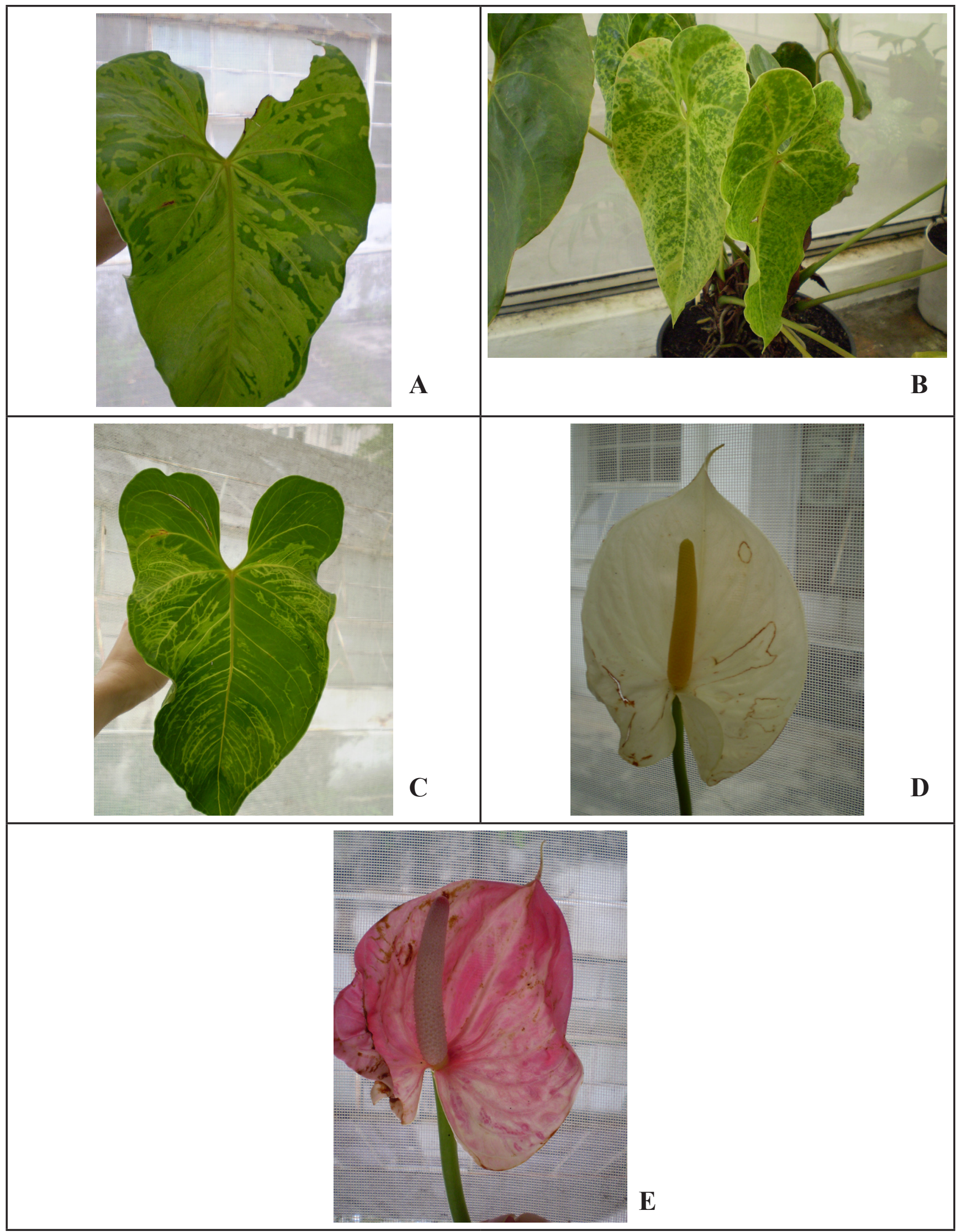

Figure 1. Symptoms observed on leaves (A, B and C) and spathes (D and E) of Anthurium andraeanum from commercial growing areas in the cities of Mogi das Cruzes, Pariquera-Acu, Iguape and Registro (sintomas observados em folhas (A, B e C) e espatas (D e E) de Anthurium andraeanum em áreas de cultivo comercial, nos municípios de Mogi das Cruzes, Pariquera-Açu, Iguape e Registro). São Paulo, Instituto Biológico, 2012. 


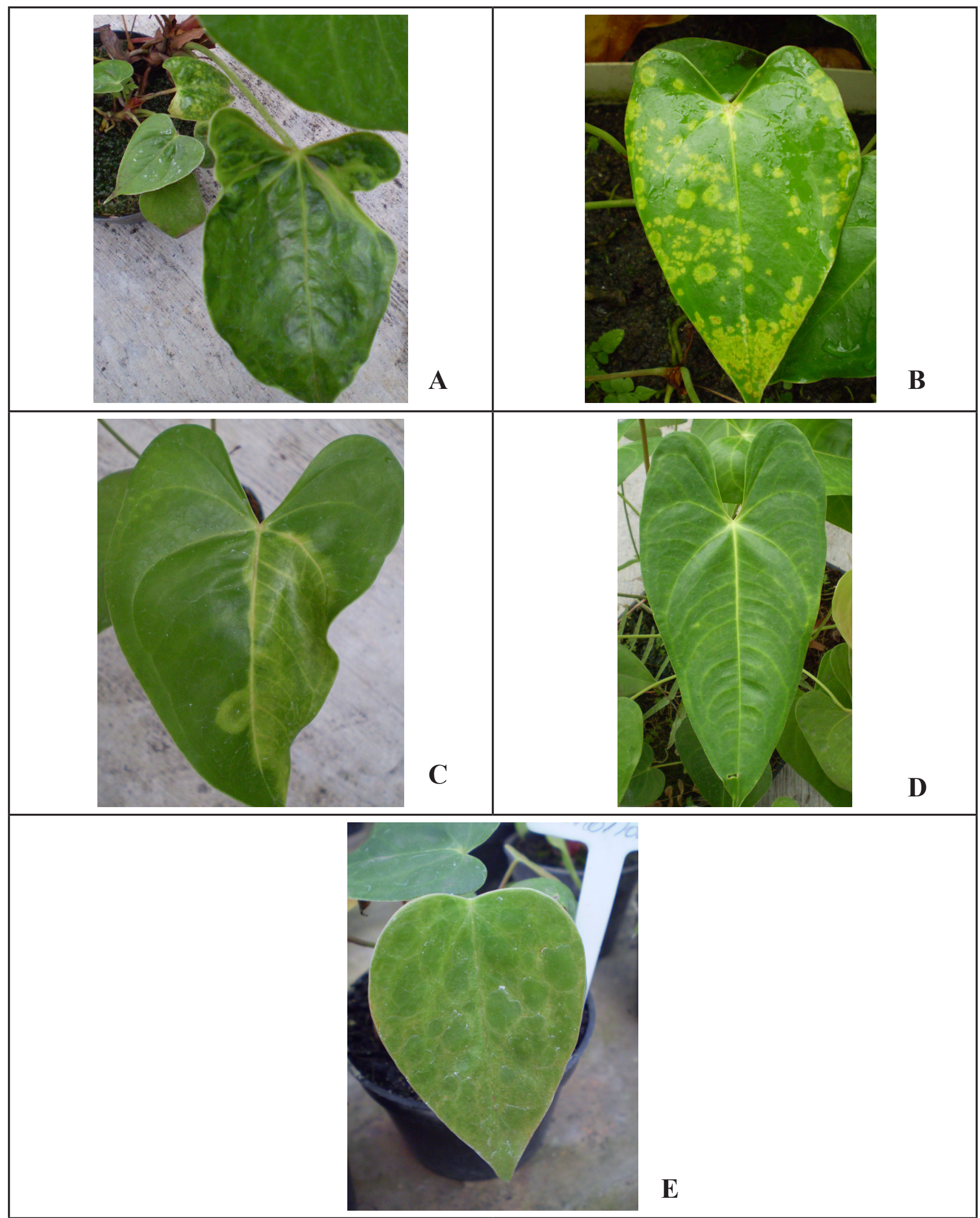

Figure 2. Symptoms induced by CMV in Anthurium andraeanum mechanically inoculated; A) cv. Branco showing mosaic, leaf deformation and blistering; B) chlorotic spots and rings in var. Astral; C) chlorotic spots that coalesce and leaf deformation observed in cv. Caipira and var. Eidibel; D) chlorotic spots, associated (var. Juréia) or not (var. Garoa) with the most prominent veins on leaves; E) blistering surrounded by necrosis in an unknown variety [sintomas induzidos por CMV em Anthurium andraeanum mecanicamente inoculados; A) cv. Branco com mosaico, bolhosidade e deformação foliar; B) manchas e anéis cloróticos na var. Astral; C) manchas cloróticas que coalescem e deformação foliar, observadas em cv. Caipira e var. Eidibel; D) manchas cloróticas, associadas (var. Juréia) ou não (var. Garoa) às nervuras mais proeminentes em folhas; E) bolhosidade com contorno necrótico em variedade desconhecida]. São Paulo, Instituto Biológico, 2012. 


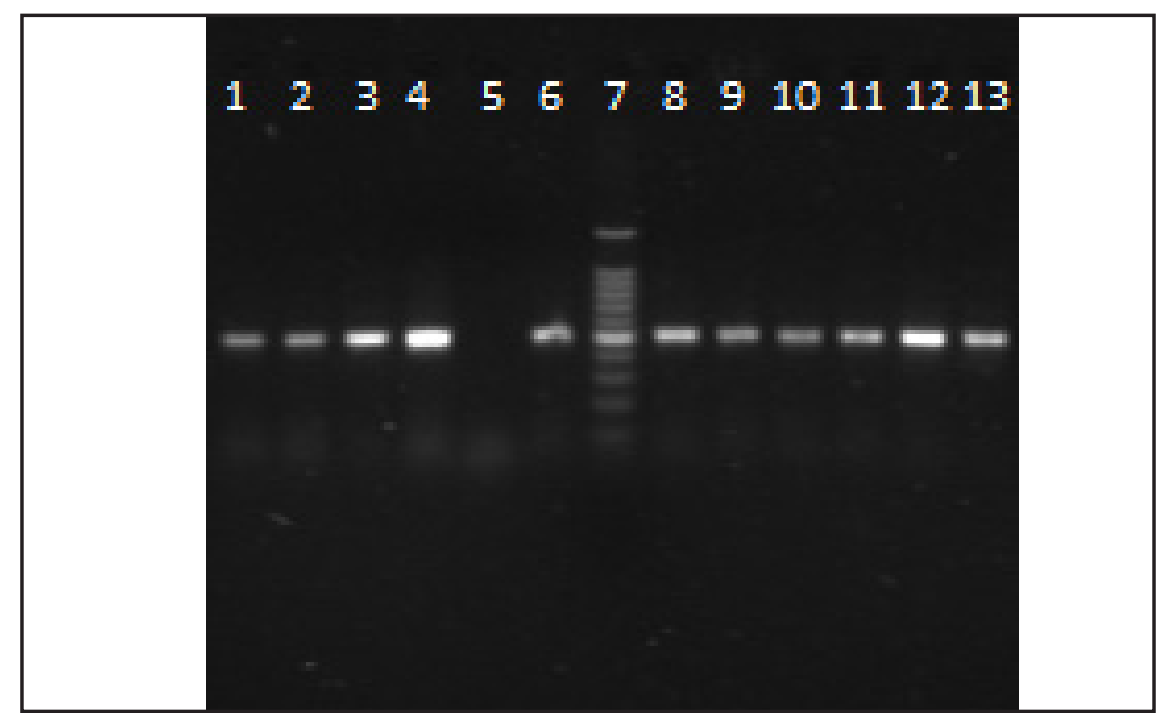

Figure 3. PCR product analysis on $1.5 \%$ agarose gel. Lanes 1 to 6 are field samples, being lane 5 a sample without symptoms; lane 7 is the $100 \mathrm{bp} \mathrm{DNA} \mathrm{Ladder} \mathrm{(Promega);} \mathrm{lanes} 8$ to 13 are anthuriums and Nicotiana glutinosa experimentally infected (análise dos produtos de PCR em gel de agarose 1,5\%. Linhas de 1 a 6 são amostras de campo, sendo a 5 uma amostra sem sintomas; a linha 7 é o marcador 100pb (Promega); linhas 8 a 13 são cultivares e variedades de antúrios experimentalmente infectados). São Paulo, Instituto Biológico, 2012.

leaves of anthurium on the induction of local lesions, even under high virus concentration, may explain the lack of virus transmission when the inoculum was prepared with naturally infected leaves.

Of the twelve inoculated species, 11 were hosts showing local reactions and/ or systemic infection. Local necrotic spots or points were observed in Gomphrena globosa (Amaranthaceae) and Chenopodiaceae species, Chenopodium amaranticolor, C. murale and C. quinoa; Nicotiana clevelandii, $N$. debneyi, N. glutinosa, N. megalosiphon, N. sylvestris and Petunia x hybrida (Solanaceae) showed local and systemic symptoms, predominantly mosaic and leaf deformation. Spathiphyllum sp. (Araceae) had not been experimentally infected. All anthurium varieties and cultivars inoculated were susceptible to the virus, differing only in the number of infected plants and in the kind of symptoms (Figure 2). The greater number of infected plants was noted in var. Astral, whereas var. Garoa and cv. Branco showed the lowest number of infected plants. The expression of symptoms in anthurium occurred between 60-90 days after inoculation (DAI), whereas in other experimental hosts symptoms could be observed between 3 and 5 DAI. Among the inoculated genotypes only 'Eidibel' and 'Garoa' showed noticeable local symptoms, i.e., chlorotic spots.

The symptoms observed in the indicator plants contributed to the choice of the antiserum and the primer pair used in ELISA and RT-PCR, respectively. According to the results obtained in this test (Figure 3), the symptomatic anthuriums collected in the four cities were infected by CMV. PTA-ELISA showed negative results when anthurium leaf extracts were used as antigens, perhaps due to the low virus concentration and/or the interference of the secondary metabolites in antigenantibody reaction, as also occurred in the transmission tests. Raj et al. (2002), evaluating the sensibility of the serological (ELISA and ISEM) and molecular (RT-PCR) methods in detecting CMV in leaves and bulbs of gladiolus, verified that the molecular tests were the most appropriate. Efficient viral RNA extraction from anthurium leaves was only possible with the use of a commercial kit, RNeasy Plant Mini Kit (Qiagen). In the protocol performed with Trizol $^{\circledR}$, RNA was not obtained possibly due to foliar tissue oxidation and/or aqueous phase inversion during the procedure. Buldewo \& Jaufeerally-
Fakim (2002) reported that it was not possible to obtain high quality DNA from $A$. andraeanum using conventional methods, and that the result was in agreement with the obtained by other authors that this was due to the presence of contaminants, such as polysaccharidelike components, secondary metabolites and phenolic compounds.

The symptoms induced by CMV in anthurium leaves differ from those induced by Tomato spotted wilt virus, which are characterized by brown necrotic leaf spots surrounded by intense yellow (Uchida et al., 1999), but are similar to those induced by Impatiens necrotic spot virus - local line patterns and concentric chlorotic rings (Mertelik et al., 2002). On the other hand, DsMV induces mosaic on leaves, color alteration and deformation in spathes (Lima et al., 2004), and depending on the anthurium variety or cultivar no differences in foliar symptoms between CMV and DsMV could be observed. In spathes presenting vein necrosis, only CMV could be detected (data not shown). The symptoms observed in naturally DsMV-infected plants (Rivas et al., 1997) as well as those related in literature for this virus are not so drastic to those induced by CMV infections, although they are similar. Drastic foliar deformation with intense mosaic was frequently observed in different varieties and cultivars. Mixed infections with CMV and DsMV were not detected.

Although both viruses, CMV and DsMV, are cosmopolitan and transmitted by aphids in a non-circulative nonpersistent manner, the DsMV is restrict to aroids and orchids Spiranthes cernua and Vanilla tahitensis (Nelson, 2008), whereas CMV infects a wide host range (Palukaitis \& García-Arenal, 2003); however, anthurium is not listed among CMV natural host.

It is possible to avoid or reduce CMV dissemination in anthurium commercial crops through elimination of weeds, mainly Commelina and Tradescantia, those are natural hosts of the virus; removal of symptomatic anthuriums with the destruction of these plants away from the cultivation area; and use of healthy propagative material. The control of aphid population not only 
in the production area but also around is important to reduce viral inoculum in medium and long term. Once the CMV is present in anthurium commercial crops, the use of resistant genotypes or that reacted with less drastic symptoms should be considered for replacement of anthuriums already cultivated.

The cultivation of different botanical species in the same area, such as observed in Mogi das Cruzes may have contributed significantly for the sporadic occurrence of CMV-infected anthuriums, since literature data show that the cultivation with a single plant species or species of the same botanical family in large areas may allow an increase in the insect vector population and consequently in viral inoculums; these factors can make impractical the anthurium cultivation in a medium or long term. The visited producers in 'Vale do Ribeira' (Registro, PariqueraAçu and Iguape) cultivate anthuriums alone or together with other Araceae, like Dieffenbachia sp.; however, the presence of CMV in anthuriums could be due to the proximity of the banana fields, which are abounding in this region and CMV infection is highly frequent (Eiras et al., 2004), so banana crops could be as a constant viral inoculum source.

\section{ACKNOWLEDGEMENTS}

The authors thank to all producers visited during the period of sampling for providing the material, seedlings and information about anthurium cultivation, as well as to ClonAgri and Mogi das Cruzes and Arujá producers for donation of anthurium seedlings. The authors wish also to thank Dr. Jesus G.
Töfoli for reading the text and giving valuable suggestions.

\section{REFERENCES}

ALMEIDA IMG; MALAVOLTA JUNIOR VA; DESTÉFANO, SAL; PARADELA FILHO O; BALANI DM; FERREIRA M; SANTOS DB. 2002. Mancha foliar em antúrio causada por Acidovorax anthurii: primeira constatação no Brasil. Summa Phytopathologica 28: 96.

BULDEWO S; JAUFEERALLY-FAKIM YF. 2002. Isolation of clean and PCR-amplifiable DNA from Anthurium andreanum. Plant Molecular Biology Reporter 20: 71a-71g.

BUSHE BC; NISHIJIMA W.T; HARAAH; SATO DM. 2004. Identifying Anthurium Flower Injuries. Plant Disease CTAHR. Available at: http://www.ctahr.hawaii.edu/oc/freepubs/ pdf/PD-25.pdf. Accessed in January 31, 2012.

DIJKSTRA J; DE JAGER CP. 1998. Practical plant virology: Protocols and exercises. New York: Springer. $459 \mathrm{p}$.

ELLIOTT MS; ZETTLER FW; BROWN LG. 1997. Dasheen mosaic potyvirus of edible and ornamental aroids. Plant Pathology Circular. Available at: http://www.freshfromflorida. com/pi/enpp/pathology/pathcirc/pp384.pdf. Acessed in January 19, 2012.

EIRAS M; BOARI AJ; CHAVES ALR; BRIONES MRS; FIGUEIRA AR; HARAKAVA. 2004. Characterization of isolates of the Cucumovirus Cucumber mosaic virus present in Brazil. Journal of Plant Pathology 86: 61-69.

FERREIRA PTO; KUBO KS; KITAJIMA EW. 2004. Ringspots in Anthurium sp. and Cordyline terminalis associated with cytoplasmic type of Brevipalpus-borne viruses. Virus Reviews \& Research 9: 249.

FIGUEIREDO ER. 1936. Floricultura brasileira. São Paulo: Bibliotheca Agricola Popular Brasileira (Chacaras e Quintais). 534 p.

GUIMARÃES JA; CASTRO ACR; MESQUITA ALM; SOBRINHO RB; AZEVEDO FR. 2008. Manual de reconhecimento e controle das principais pragas do antúrio no Estado do Ceará. Documentos 114. Embrapa. 20p.

LACERDA JP. 2006. Doenças fúngicas e bacterianas em algumas espécies de Araceae. Lavras: UFLA. 81p (Dissertação mestrado).

LIMA RCA; LIMA JA; AGUIAR JR. 2004. Serological identification of Dasheen mosaic virus in Anthurium sp. in the State of Ceará.
Fitopatologia Brasileira 29: 105.

MERTELIK J; MOKRA V; GOTZOVA B; GABRIELOVA S. 2002. Occurrence and identification of Impatiens necrotic spot virus in the Czech Republic. Acta Horticulturae 568: 79-83.

NELSON SC. 2008. Dasheen mosaic of edible and ornamental aroids. Plant Disease CTAHR. Available at: http://www.ctahr.hawaii.edu/oc/ freepubs/pdf/PD-44.pdf. Accessed in January 23, 2012.

PALUKAITIS P; GARCÍA-ARENAL F. 2003. Cucumber mosaic virus. Descriptions of Plant Viruses. Available at: www.dpvweb. net/dpv/showdpv.php?dpvno=400. Accessed in January 18, 2012.

RAJ SK; SRIVASTAVAA; CHANDRA G; SINGH BP. 2002. Characterization of Cucumber mosaic virus isolate infecting Gladiolus cultivars and comparative evaluation of sorological and molecular methods for sensitive diagnosis. Current Science 83: 1132-1137.

RIVAS EB; DUARTE LML; ALEXANDRE MAV; GALLETI SR. 1997. Dasheen mosaic virus in Anthurium species. Virus Reviews \& Research 2: 192-193.

ROBBS CF. 1953. A mancha bacteriana das aráceas. Agricultura e Pecuária, Rio de Janeiro 24: 18-19.

TOMBOLATO AFC; FURLANI PR; CASTRO CEF; MATHES LAF; TAGLIACOZZO GMD; SAES LA; RIVAS EB; COUTINHO LC; BERGMAN EC; IMENES SL; COSTA AMM; LEME JM. 2004. Antúrio Anthurium andraeanum Lindl. In: TOMBOLATO AFC (ed). Cultivo comercial de plantas ornamentais. Campinas: Instituto Agronômico de Campinas. p. 61-94.

UCHIDA JY; OGATA D; NAGATA N. 1999. Tomato spotted wilt virus on Anthurium. Plant Disease CTAHR. Available at http://www. ctahr.hawaii.edu/oc/freepubs/pdf/PD-17.pdf. Accessed on January 31, 2012.

VERPLANCKE G. 1930. Une maladie "a virus infiltrant" des Anthurium. Comptes Rendus de la Societe de Biologie (Paris) 103: 524-526.

WYLIE S; WILSON CR; JONES RAC; JONES MGK; 1993. A polymerase chain reaction assay for Cucumber mosaic virus in lupin seeds. Australian Journal Agricultural Research 44:41-51.

ZETTLER FW; HARTMAN RD. 1987. Dasheen mosaic virus as a pathogen of cultivated aroids and control of the virus by tissue culture. Plant Disease 71: 958-963. 